\title{
COMPARISON BETWEEN SOME PHYSICAL AND CHEMICAL PROPERTIES OF MOLLISOLS AND VERTISOLS IN KURDISTAN REGION, IRAQ
}

\author{
Hedi M. Ossman ${ }^{*}$ and Mohammed A. FAyyadH ${ }^{* *}$ \\ *Dept. of Soil and Water Sciences, College of Agricultural Engineering Sciences, \\ University of Salahaddin, Kurdistan Region, Iraq \\ *** Dept. of Soil and Water Sciences, College of Agricultural Engineering Sciences, \\ University of Duhok, Kurdistan Region, Iraq
}

(Received: April 24, 2021; Accepted for Publication: May 19, 2021)

\begin{abstract}
This study was conducted to compare some soil physical and chemical properties of Mollisols and Vertisols in Kurdistan Region, Iraq. Four pedons were chosen, two in each location. Soil samples from horizons were taken. Soil samples were air-dried, ground and sieved by $(2 \mathrm{~mm})$ sieve in order to be used for physical and chemical analyses. The results indicated that the soil reaction $(\mathrm{pH})$ was slightly alkaline (7.97- 8.35). Electrical conductivity in all soil samples of both soil orders Vertisols, and Mollisols are low due to the leaching process by the rainfall additionally; these soil orders have well drainage conditions. Organic matter content was concentrated at the surface horizon (Ap) in both study soil orders, both littering and humification processes are predominant in surface horizon and appear mollic epipedon in Mollisols. The Vertisols contained considerable organic matter content but less than Mollisols. Vertisols contained more carbonates notably in the deep soil horizons. Generally, there is an increase in total carbonates content with depth. High cation exchange capacity (CEC) which decreased directly towards downward of soil profile. CEC values in vertisols were relatively higher than in Mollisols. Fluctuation in bulk density among soil horizons in Vertisols, whereas in Mollisols they were increased in bulk with depth. Clay content in Vertisols increased with depth.
\end{abstract}

KEYWORDS: Vertisols, Mollisols, Carbonates, Clay, organic matter, Melanization, Lessivage.

\section{INTRODUCTION}

$\mathbf{M}$ ollisols commonly are dark-colored, base-rich mineral soils of the steppes. Nearly all of these have a mollic epipedon, and many have calcic horizon (Muhaimeed et al, 2014). Mollisols can have any moisture regime, but enough available moisture to support perennial grasses seems to be essential, and may be in areas of older deposits and commonly have an argillic horizon in warmer areas where slopes are not too steep (Janzen et al., 2011). These soils are typically well saturated with basic cations (Calcium, Magnesium, Sodium and Potassium) that are essential plant nutrients. Mollisols are most fertile soils and easily cultivated, commonly without irrigation and addition of fertilizers (Eswaran and Reich, 2005). According to Soil Survey Staff, (1999) the most important soil forming process of Mollisol is melanization (darkening of the soil by organic matter additions). Muhaimeed et al, (2013) showed that Mollisols are commonly dark-colored, base-rich mineral soils of the steppes. Nearly all of these have a mollic epipedon, and many have an argillic, and calcic horizon. Many of these soils developed under grass and many apparently were forested.

Vertisols are a relatively homogeneous soil group, they occur in a wide range of climatic environments globally and also show considerable variability in their uses and crop productivity (Pal et al. 2012b). The clayenrichment of Bss horizons via illuviation suggests that the argilli-turbation is not a primary pedogenetic process in Vertisols (Pal et al. 2009a). The illuviation of clay in the absence of slickensides therefore indicates that illuviation is a faster pedogenetic process than the formation of slickenside (Singh et al. 1998). Vertisols are usually very dark in color, with widely variable organic matter content (1-6\%). 
Generally, these soils form in $\mathrm{Ca}$ and $\mathrm{Mg}$ rich parent materials such as limestone, basalt, and typically formed in depression topography. Vertisols are most commonly formed in warm, sub-humid or semi-arid climates, where the natural vegetation is predominantly grass, savanna, open forest, or desert shrub (Sa'eb and Taimeh,1998). The physical and chemical data for the pedons in the mountain region meet the criteria for the formation of some diagnostic horizons including Mollic, Calcic and to some extent the formation of Cambic and Argillic horizons. Vertisols are clayey soils that have deep, wide cracks for some time during the year and have slickensides within $100 \mathrm{~cm}$ of the mineral soil surface (Muhaimeed et al, 2013). Vertisols generally have high clay content (50 to $70 \%$ ) and a relatively large proportion of fine clay in the clay fraction (Soil Taxonomy, 2012). Vertisols is not necessarily indicative of high organic matter content. However, subsidiary processes, such as fluctuations in the moisture status, accumulation of organic matter, carbonates, gypsum or soluble salts and acidification processes through leaching result in the differences within the Vertisols (FAO, 2015).

Due to the presence of these two soil orders in some parts of Kurdistan region -Iraq, so this study aims to comparison some physical and chemical properties of Mollisols and Vertisol, specify pedogenic processes and diagnostic horizons in both soil orders..

\section{METHODS AND MATERIALS}

\subsection{Study Area and Soil Sampling}

The study area was located in Kurdistan region in both Halabja and Duhok provinces (Figure, 1) and (Table,1). Four pedons were dug, two in each location with specifying soil horizons and pedon description depending on the key to soil taxonomy (Soil survey staff, 2010). Soil samples were air-dried, ground and sieving by $(2 \mathrm{~mm})$ sieve then kept in polythene bags in order to be used for the laboratory analyses. Average rainfall for (10) years in Duhok and Halabja sites was $(455.8 \mathrm{~mm})$ and $(640.1 \mathrm{~mm})$ respectively and the average temperature was $\left(22.3 \mathrm{C}^{\circ}\right)$ and $\left(22.5 \mathrm{C}^{\circ}\right)$ (Table, 2).

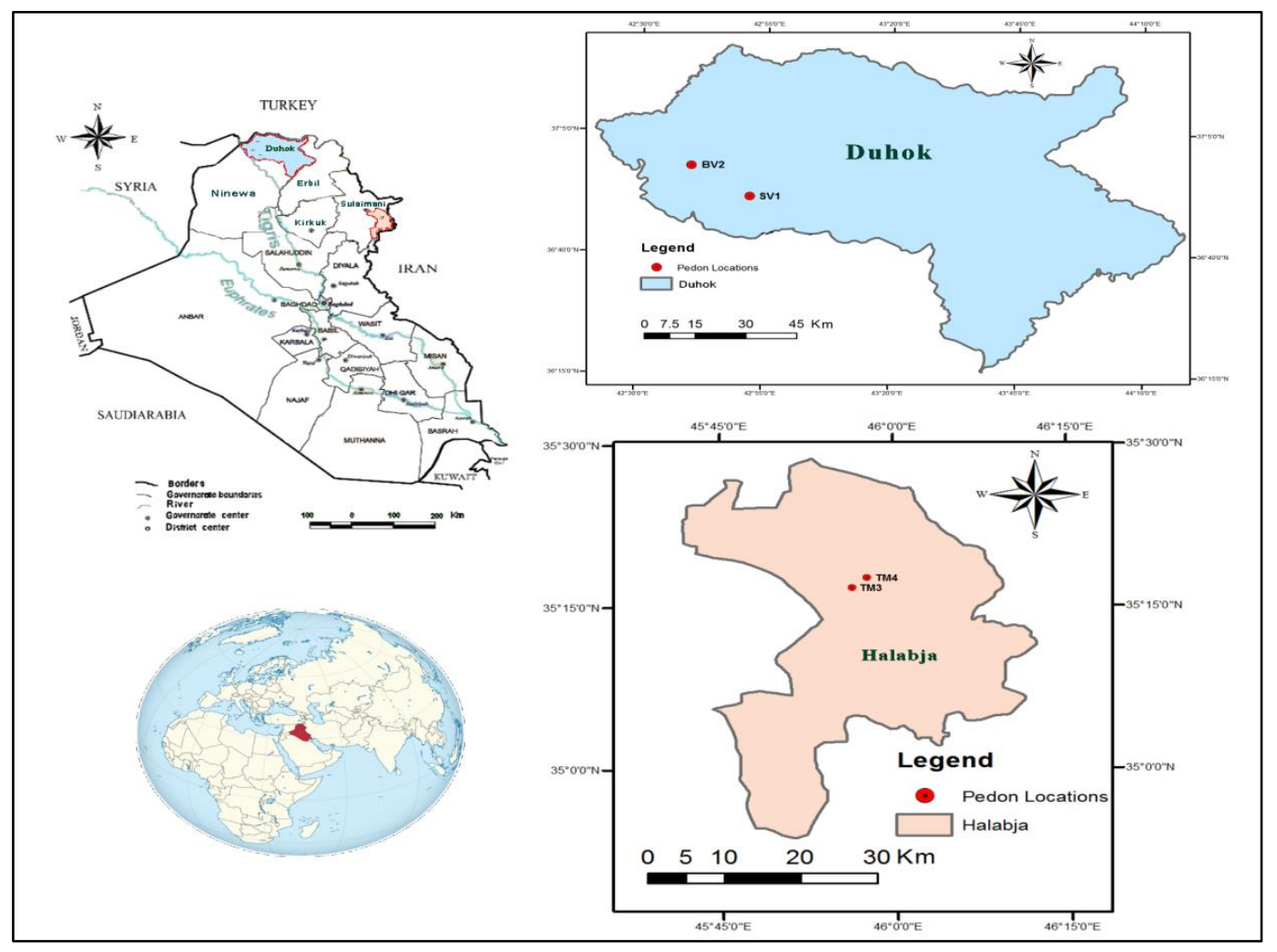

Fig. (1): Map of Study sites 
Table (1): GPS Coordination for Studied Pedons

\begin{tabular}{|c|c|c|c|c|c|c|}
\hline Province & Soil Order & Site & Pedon & Latitude $(\mathrm{N})$ & Longitude (E) & Altitude $(\mathrm{m})$ \\
\hline \multirow{2}{*}{$\begin{array}{l}\text { 모 } \\
\text { 몸 }\end{array}$} & & Simiel & $\overline{\text { SV1 }}$ & $36^{\circ} 51^{\prime} 40^{\prime \prime}$ & $42^{\circ} 51^{\prime} 55^{\prime \prime}$ & 495 \\
\hline & & Baatel & BV2 & $36^{\circ} 57^{\prime} 56^{\prime \prime}$ & $42^{\circ} 40^{\prime} 11^{\prime \prime}$ & 521 \\
\hline \multirow{2}{*}{$\frac{\frac{\pi}{\alpha}}{\frac{\pi}{\pi}}$} & & Tapa-gulawi & TM3 & $35^{\circ} 16^{\prime} 51^{\prime \prime}$ & $45^{\circ} 56^{\prime} 15^{\prime \prime}$ & 510 \\
\hline & & Tapa-tolaka & TM4 & $35^{\circ} 17^{\prime} 49^{\prime \prime}$ & $45^{\circ} 57^{\prime} 28^{\prime \prime}$ & 532 \\
\hline
\end{tabular}

Table (2): Rainfall and temperature in studied sites

\begin{tabular}{|c|c|c|c|c|c|c|c|}
\hline$\stackrel{\Phi}{\stackrel{\omega}{\omega}}$ & 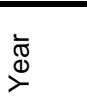 & $\begin{array}{c}\text { Average } \\
\text { Rainfall } \\
(\mathrm{mm})\end{array}$ & $\begin{array}{c}\text { Average } \\
\text { Temp. } \\
\left(\mathrm{C}^{\circ}\right)\end{array}$ & $\frac{\Phi}{\omega}$ & ঠ্ঠ & $\begin{array}{c}\text { Average } \\
\text { Rainfall } \\
(\mathrm{mm})\end{array}$ & $\begin{array}{c}\text { Average } \\
\text { Temp. } \\
\left(\mathrm{C}^{\circ}\right)\end{array}$ \\
\hline \multirow{10}{*}{$\begin{array}{l}\frac{y}{0} \\
\frac{x}{3}\end{array}$} & 2009 & 421.6 & 22.3 & \multirow{10}{*}{$\frac{\frac{\pi}{2}}{\frac{\pi}{\pi}}$} & 2011 & 629.2 & 22.8 \\
\hline & 2010 & 301.0 & 23.1 & & 2012 & 590.8 & 23.4 \\
\hline & 2011 & 376.0 & 21.0 & & 2013 & 675.4 & 20.8 \\
\hline & 2012 & 382.9 & 22.1 & & 2014 & 486.4 & 22.8 \\
\hline & 2013 & 522.1 & 21.5 & & 2015 & 554.7 & 22.3 \\
\hline & 2014 & 649.5 & 22.4 & & 2016 & 796.7 & 23.0 \\
\hline & 2015 & 415.0 & 22.4 & & 2017 & 506.6 & 22.4 \\
\hline & 2016 & 367.5 & 22.9 & & 2018 & 535.6 & 21.2 \\
\hline & 2017 & 281.3 & 21.7 & & 2019 & 1081.4 & 22.9 \\
\hline & 2018 & 841.1 & 24.0 & & 2020 & 544.1 & 23.1 \\
\hline \multicolumn{2}{|c|}{$\begin{array}{l}10 \text { Yearly } \\
\text { Average }\end{array}$} & 455.8 & 22.3 & \multicolumn{2}{|c|}{$\begin{array}{l}10 \text { Yearly } \\
\text { Average }\end{array}$} & 640.1 & 22.5 \\
\hline
\end{tabular}

\subsection{Laboratory Analysis}

Particle sizes distribution was determined by the hydrometer method as adopted by Klute (1986). Soil bulk density was estimated using the paraffin coated clod method (Black, 1965). Soil $\mathrm{pH}$ and EC measured in soil suspension (1:1) as described by Rowell (1996). Organic matter determined according to Walkely and Black (1965). Cation exchange capacity was measured as described by Polemio and Rhoads, (1977). Calcimeter device was used to specify total carbonate as described by Loeppert and Suarez (1996).

\section{RESULTS AND DISCUSSION \\ $3.1 \mathrm{pH}$ and EC}

The soil reaction $(\mathrm{pH})$ was slightly alkaline (7.97- 8.35) (Table, 3) this was attributed to the existence of some cations whereas; study soils were derived from limestone parent material. Despite there is no considerable differences among $\mathrm{pH}$ values of different soil horizons in study pedons, the results showed in that $\mathrm{pH}$ values fluctuated between increase and decrease in Vertisols, this fluctuation may be due to the existence of cracks and translocation of different cations amount throughout the soil pedon, in addition to the effect of organic matter that was translocated from epipedons to subsurface horizons through cracks that caused a decrease in $\mathrm{pH}$ values when increasing their content. Generally, $\mathrm{pH}$ values increased towards downward of pedon in Mollisols. In line with this, the low value found at the surface horizon in both study soil orders; this was due to increasing organic matter in surface horizon of the soil (Ap).

Conspicuously, the results revealed scant values of electrical conductivity in all soil samples in all study pedons of both Vertisols, and Mollisols. These low values of EC proved the study soils were non-saline and occurred desalinization process. The low values of electrical conductivity for the Vertisols and Mollisols are due to the leaching process by the rainfall additionally; these soil orders have well drainage conditions (Table, 2). 
Table (3): Some chemical properties of study soil orders

\begin{tabular}{|c|c|c|c|c|c|c|c|c|c|c|}
\hline \multirow[b]{2}{*}{ 元 } & \multirow{2}{*}{ 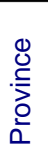 } & \multirow[t]{2}{*}{ Site } & \multirow[t]{2}{*}{ Pedon } & \multirow[t]{2}{*}{ Horizon } & \multirow[t]{2}{*}{ Depth (cm) } & $\begin{array}{c}\text { Total } \\
\mathrm{CaCO}_{3} \\
\end{array}$ & $\begin{array}{c}\text { Organic } \\
\text { matter }\end{array}$ & \multirow[t]{2}{*}{$\begin{array}{c}\text { CEC } \\
\left(\mathrm{Cmol}_{\mathrm{c}} \cdot \mathrm{kg}^{-1}\right)\end{array}$} & \multirow[t]{2}{*}{$\mathrm{pH}$} & \multirow[t]{2}{*}{$\mathrm{EC}\left(\mathrm{dS} \cdot \mathrm{m}^{-1}\right)$} \\
\hline & & & & & & \multicolumn{2}{|c|}{$\mathrm{g} \cdot \mathrm{Kg}^{-1}$} & & & \\
\hline \multirow{7}{*}{ 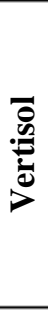 } & \multirow{7}{*}{$\begin{array}{l}\text { 등 } \\
\text { 돔 } \\
\text { Dิ }\end{array}$} & Simiel & SV1 & Ap & $0-23$ & 157.3 & 12.3 & 37.26 & 8.20 & 0.29 \\
\hline & & & & Bt1 & $23-56$ & 139 & 7.8 & 33.21 & 8.25 & 0.24 \\
\hline & & & & Bssk2 & $56-123$ & 264.9 & 2.6 & 30.64 & 8.28 & 0.25 \\
\hline & & Baatel & BV2 & Ap & $0-22$ & 249.2 & 12.3 & 40.5 & 8.28 & 0.23 \\
\hline & & & & Btk1 & $22-42$ & 274.1 & 9.5 & 37.26 & 8.18 & 0.25 \\
\hline & & & & Btk2 & $42-86$ & 215.2 & 12.3 & 34.83 & 8.35 & 0.24 \\
\hline & & & & Bssk3 & $86-150$ & 298 & 9.5 & 32.97 & 8.16 & 0.28 \\
\hline \multirow{6}{*}{ 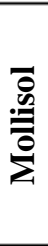 } & \multirow{6}{*}{$\frac{\frac{\pi}{0}}{\frac{\pi}{\pi}}$} & Tapa- & TM3 & Ap & $0-72$ & 234.1 & 21.3 & 39.25 & 8.04 & 0.29 \\
\hline & & gulawi & & Bkt & $72-104$ & 232.6 & 13.4 & 34.83 & 8.35 & 0.27 \\
\hline & & & & Ck & $104-140$ & 350.6 & 8.2 & 32.97 & 8.28 & 0.28 \\
\hline & & tolaka & & $\mathrm{Bt}$ & $22-72$ & 117.5 & 18.2 & 39.26 & 7.97 & 0.34 \\
\hline & & & & Ck1 & $72-102$ & 161.4 & 6.7 & 32.35 & 8.21 & 0.23 \\
\hline & & & & Ck2 & $102-155$ & 182.1 & 9.4 & 27.54 & 8.22 & 0.21 \\
\hline
\end{tabular}

\subsection{Organic Matter}

Soil organic matter was ranged between (2.6) g. $\mathrm{Kg}^{-1}$ in (Bssk2) horizon of pedon (SV1) and (26.2) $\mathrm{g} . \mathrm{Kg}^{-1}$ in (Ap) horizon of pedon (TM4) (Table, 3). Organic matter content was concentrated at the surface horizon (Ap) in both study soil orders as a result of increasing litter accumulation at the surface soil and increase organisms activity that plays a major role in decomposition residuals of organic matter in turn increasing humified organic matter more than the subsurface and deep soil horizons, therefore both littering and humification processes are predominant in surface horizon and appear mollic epipedon in Mollisols, this results agreed with Muhaimeed et al, (2014). Although, Vertisols contained considerable organic matter content but there is less than Mollisols. The results also showed organic matter oscillation from one horizon to another in Vertisols this is due to the cracks when organic matter transported from the surface to the subsurface and deep horizons through cracks and self-churning of the soil by pedoturbation process, in turn, caused the fluctuation of organic matter content among soil horizons. Relatively high values of organic matter content was found in Mollisols and related with existing of the suitable soil moisture regime and soil temperature regime (Table, 2)that plays an important role in an increasing organism's activity that acts for decomposing organic litter particularly in (Ap) horizon which is represent the roots zone and organisms activity. The results showed translocation of organic matter content through cracks from surface to subsurface and deep horizons by up- to- down of the soil materials and mixing process as a result of shrinking and swelling in Vertisols, and this was agreed with Pal et al. (2012b), whereas the Mollisols have a high organic matter content because of increased residuals of plants and grasses on the soil surface. The distribution pattern of organic matter with depth showed fluctuation between increase and decrease in both vertisols pedons (SV1) and (BV2). Whilst in Mollisols the distribution pattern was decreasing of organic matter with depth (Figure, 2 ), this figure proved the results about organic matters as mentioned above. 


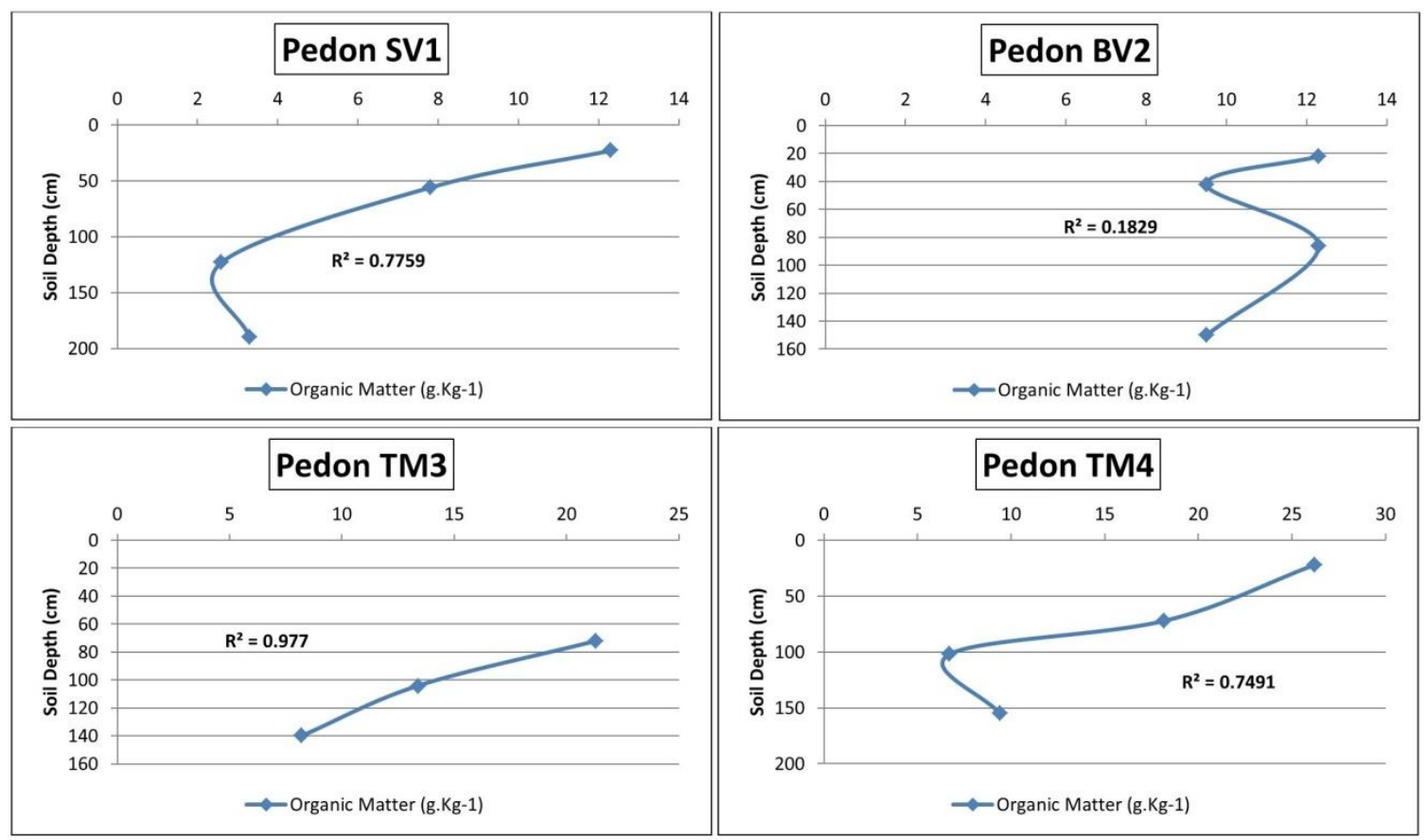

Fig/ (2): Vertical distribution of organic matter in study pedons

\subsection{Total Carbonates}

Total carbonates in Vertisols ranged between (139- 298) in (Bt1) and (Bssk3) horizons (Table, 3). The results revealed oscillation in total carbonates among soil horizons in all study pedons of Vertisols, this may be due to the swelling- shrinking with exist the cracks in addition to the effect of rainfall that causes translocation of carbonates by water to different soil horizons. Commonly, Vertisols contained high total carbonates notably in the deep soil horizons (Bssk3, and Bssk2); this is attributed to the effect of parent material which is considered calcareous. Similarly, the distribution pattern of total carbonates in Vertisols indicated an increase of it with the soil depth in spite of minor fluctuations in their values among soil horizons, this may be related to the rainfall effect (Table, 2) and translocation of total carbonates downward (Figure, 3).

Correspondingly, in Mollisols, total carbonates content ranged between (110.9- 350.6 g. $\left.\mathrm{Kg}^{-1}\right)$ in (Ap) and (Ck) horizons in pedon (TM4) and (TM3) respectively (Table, 3). In the same manner as in Vertisols a high accumulation of total carbonates in deep soil horizons in all study pedons in Mollisols as a result of the rainfall effect and leaching process that caused translocate of carbonates from surface to subsurface and deep horizons. Although there are no considerable differences between study soil orders, consistently total carbonates in Mollisols were more than Vertisols this is attributed to the conditions of formation of each soil order particularly that is related with weathering process and degree of soil development. Generally, there is an increase in total carbonates content with depth down soil pedon (Figure, 3). The total carbonates content and distribution along soil horizons indicated to the dominance of calcification as an important pedogenic

process. 


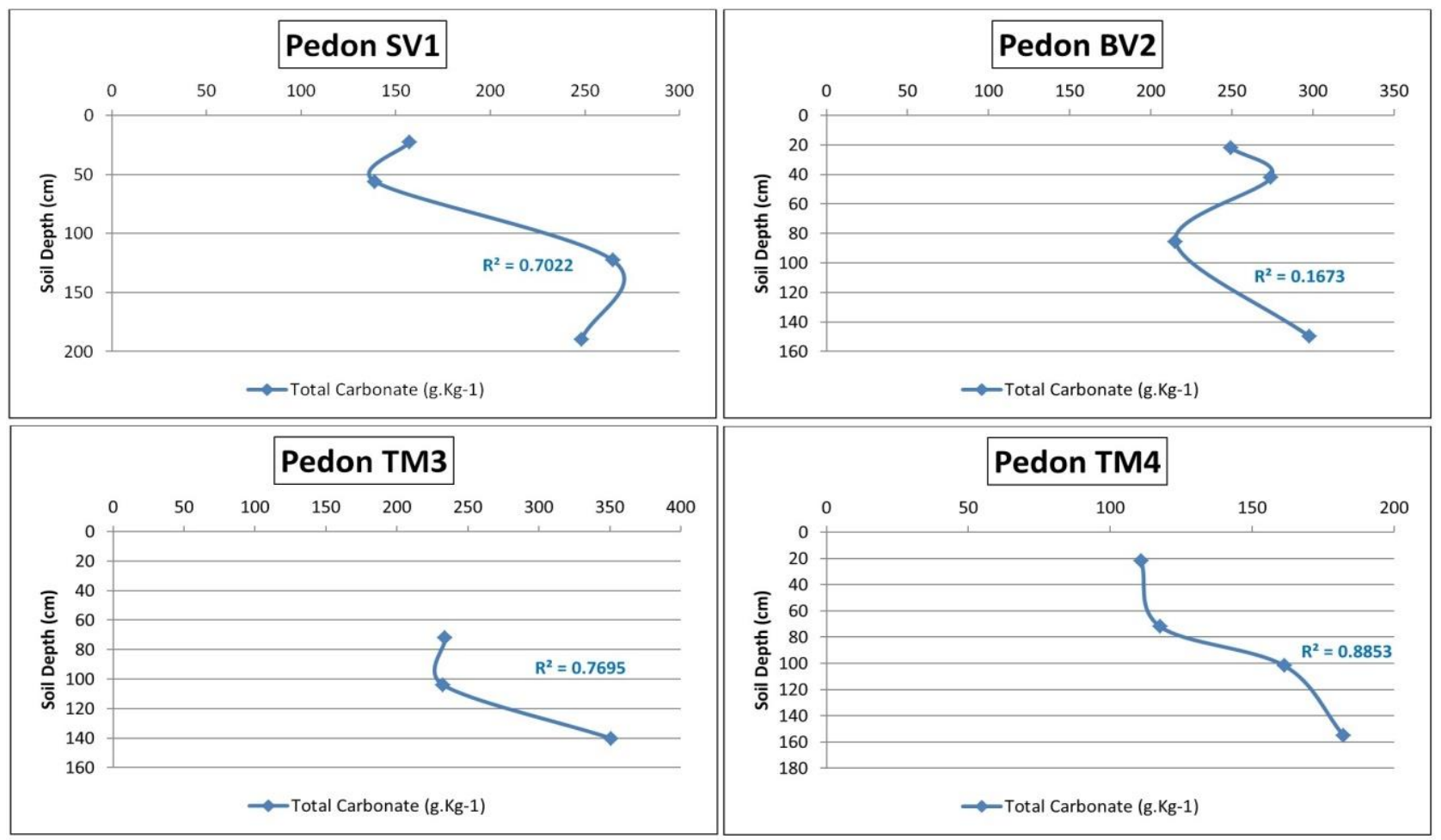

Fig. (3): Vertical distribution of total carbonates in study pedons

\subsection{Cation Exchange Capacity (CEC)}

The results showed high cation exchange capacity (CEC) in Vertisols and Mollisols (40.50 and 40.45 Cmole. $\mathrm{Kg}^{-1}$ ) (Table, 3) because both of them contain high organic matter content. Generally, the CEC value decreased directly towards downward of study pedons in both mollisols and vertisols and this distribution pathway due to the relatively high organic matter content in the surface horizon in both Mollisols and Vertisols and decrease with depth (Table, 3 ). It is worth mentioning, CEC values in vertisols were relatively higher than in Mollisols along the down direction of the pedons as a result of high clay content in this soil order which corresponding to the requirements of Vertisols formation in addition to the effect of organic matter that was translocated to subsurface soil horizons through cracks and pedoturbation by self-churning with up to down as a result of swelling and shrinking process, in turn, contribute in increase CEC values in subsurface horizons in Vertisols more than Mollisols. The distribution pattern of CEC with depth indicated the semi steady-state and gradually decrease with depth but in vertisols was relatively steadier than Mollisols because the organic matter distribution in Vertisols horizons was more homogenize than Mollisols (Figure, 4), the high CEC values attributed to the well saturated study soils with basic cations and these results proved by Eswaran and Reich, (2005). 


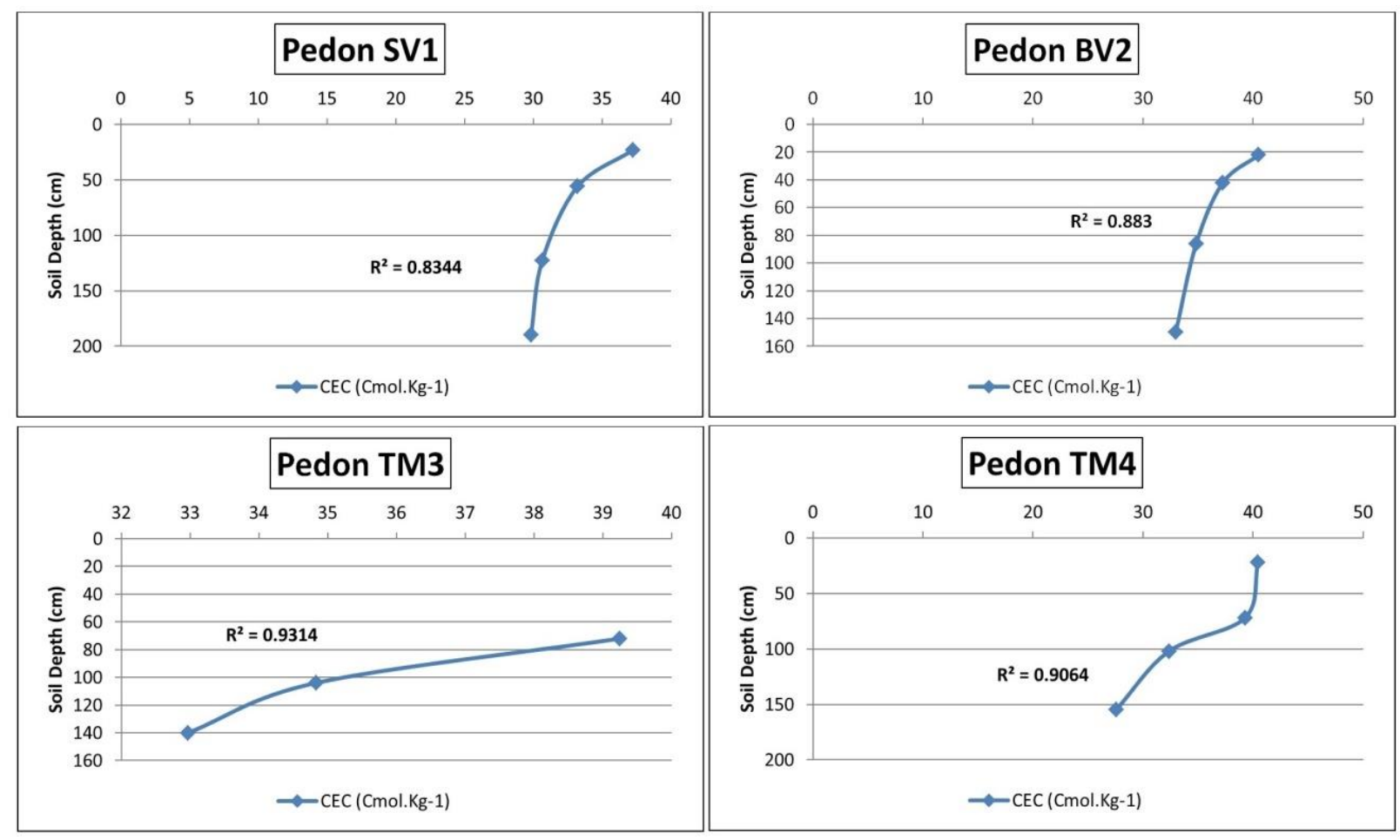

Fig. (4): Vertical distribution of CEC in study pedons

\subsection{Soil Bulk Density}

Vertisols, bulk density was ranged between $\left(1.28 \mathrm{Mg} \cdot \mathrm{m}^{-3}\right)$ in (Btk2) horizon in pedon (BV2) and $\left(1.84 \mathrm{Mg} . \mathrm{m}^{-3}\right)$ in (Bssk2) horizon in pedon (SV1) (Table, 4). Despite there is a lower value of bulk density in the surface horizon (Ap) in the pedons of Vertisols because of the effect of organic matter but the results in this soil order revealed fluctuation in the bulk density among soil horizons and this fluctuation was due to the high clay content, and organic matter effect that was translocated to subsurface and deep horizons through cracks. It is worth mentioning the bulk densities in all horizons of pedon (BV2) have low values compared with soil horizons of pedon (SV1) and attributed to the high clay content in pedon (BV2) more than pedon (SV1) in addition to the effect of organic matter content.
On the other hand, the bulk density in Mollisols ranged between $\left(1.40 \mathrm{Mg} \cdot \mathrm{m}^{-3}\right)$ in the surface horizon (Ap) in pedon (TM4) and (1.88 $M \mathrm{~g} . \mathrm{m}^{-3}$ ) in the horizon (Ck1) in pedon (TM4), the results revealed an increase in bulk density values with depth in two pedons this was attributed to the effect of high organic matter content in surface horizons that caused aggregates formation and has negative relationship with soil bulk density, as well as the high clay amount, another factor that decreases soil bulk density, whilst the low organic matter content in the subsurface horizons, in addition, the soil texture tends to be coarse and contains a considerable amount of sand fraction that led to increase bulk density. Commonly, the soil bulk density in Mollisols was less than those in Vertisols. 
Table (4): Some physical properties of study pedons

\begin{tabular}{|c|c|c|c|c|c|c|c|c|c|c|}
\hline \multirow{2}{*}{ के } & \multirow[t]{2}{*}{ Province } & \multirow[t]{2}{*}{ Site } & \multirow[t]{2}{*}{ Pedon } & \multirow[t]{2}{*}{ Horizon } & \multirow[t]{2}{*}{ Depth (cm) } & \multicolumn{3}{|c|}{$\begin{array}{c}\text { Particle Size Distribution } \\
\left(\mathrm{g} \cdot \mathrm{kg}^{-1}\right)\end{array}$} & \multirow[t]{2}{*}{ Texture } & \multirow[t]{2}{*}{$\begin{array}{l}\text { Bulk density } \\
\left(M^{\prime} \cdot \mathrm{kg}^{-1}\right)\end{array}$} \\
\hline & & & & & & Sand & Silt & Clay & & \\
\hline \multirow{8}{*}{ 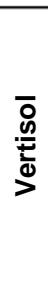 } & \multirow{8}{*}{$\begin{array}{l}\text { 음 } \\
\text { 돔 }\end{array}$} & \multirow[t]{4}{*}{ Simiel } & \multirow[t]{4}{*}{ SV1 } & $A p$ & $0-23$ & 143 & 310 & 547 & Clay & 1.51 \\
\hline & & & & $\mathrm{Bt} 1$ & $23-56$ & 117 & 285 & 598 & Clay & 1.70 \\
\hline & & & & Bssk2 & $56-123$ & 164 & 260 & 576 & Clay & 1.84 \\
\hline & & & & Ck & $123-190$ & 160 & 210 & 630 & Clay & 1.73 \\
\hline & & \multirow[t]{4}{*}{ Baatel } & \multirow[t]{4}{*}{ BV2 } & $\mathrm{Ap}$ & $0-22$ & 180 & 250 & 570 & Clay & 1.45 \\
\hline & & & & Btk1 & $22-42$ & 188 & 200 & 612 & Clay & 1.32 \\
\hline & & & & Btk2 & $42-86$ & 174 & 200 & 626 & Clay & 1.28 \\
\hline & & & & Bssk3 & $86-150$ & 203 & 200 & 597 & Clay & 1.30 \\
\hline \multirow{7}{*}{$\begin{array}{l}\bar{o} \\
\stackrel{\text { D }}{\overline{0}} \\
\text { 을 }\end{array}$} & \multirow{7}{*}{$\frac{\frac{\pi}{0}}{\frac{\pi}{\pi}}$} & \multirow{3}{*}{$\begin{array}{l}\text { Tapa- } \\
\text { gulawi }\end{array}$} & \multirow[t]{3}{*}{ TM3 } & $A p$ & $0-72$ & 98 & 275 & 627 & Clay & 1.45 \\
\hline & & & & Bkt & $72-104$ & 120 & 250 & 630 & Clay & 1.58 \\
\hline & & & & $\mathrm{Ck}$ & $104-140$ & 148 & 300 & 552 & Clay & 1.61 \\
\hline & & \multirow{4}{*}{$\begin{array}{l}\text { Tapa- } \\
\text { tolaka }\end{array}$} & \multirow[t]{4}{*}{ TM4 } & $\mathrm{Ap}$ & $0-22$ & 170 & 275 & 555 & Clay & 1.40 \\
\hline & & & & $\mathrm{Bt}$ & $22-72$ & 195 & 250 & 555 & Clay & 1.63 \\
\hline & & & & Ck1 & $72-102$ & 420 & 230 & 350 & Clay Loam & 1.88 \\
\hline & & & & Ck2 & $102-155$ & 208 & 492 & 300 & Clay Loam & 1.69 \\
\hline
\end{tabular}

\subsection{Particles Size Distribution and Soil Texture}

The clay content in Vertisols generally increases and fluctuated with depth in the study pedons (SV1), and (BV2) (Table, 4) because of translocation of clay from upper horizons to subsurface and deep soil horizons. In concordance with this, the soil texture in all horizons of study pedons has the clayey texture. Despite the clay content tends to decrease in the subsurface horizon occasionally but the vertical distribution pattern indicated fluctuation in clay with depth in this soil order particularly in pedon (SV1) (Figure, 5). Evidently, there are no large differences in the silt content among soil horizons in the study pedons in Vertisols and generally, there are low values of sand in study pedons in Vertisols, but there are high contents of clay and silt fractions and this is due to the high effect of soil-forming factors and the large severity of pedogenic processes, in line with this, the soil becomes more development, these results similar to the results obtained by soil survey staff, soil taxonomy, (2012).

Conspicuously, there is high clay content in all soil horizons for both pedons in Mollisols order and accordingly, the soil was the fine texture (Clay, and Clay loam) and this reflects the active role of geogenic and pedogenic processes in this soil order. Clay distribution pattern with depth showed decreases in both pedons for Mollisols in spite of the existing considerable amount of clay along soil pedon in all horizons as a result of high intensity of soilforming factors and processes (Figure, 5). The silt fraction coming in the second-order after clay as concerning their amount. In line with this, the considerable silt content plays an important role in improving soils properties. The sand fraction generally, has the lowest value in the study soil horizons in Mollisols, this may be due to the effect of climate and relatively increase weathering which has caused decreased sand fraction (Table, 2). On the other hand, although existence the relatively high amount of sand separate in some soil horizons in Mollisols $\left(420\right.$ g. $\left.\mathrm{Kg}^{-1}\right)$ in $(\mathrm{Ck} 1)$ horizon in pedons (TM4) did not have a high effect on the soil texture and other chemical properties because of the sand particles are charge-less. 


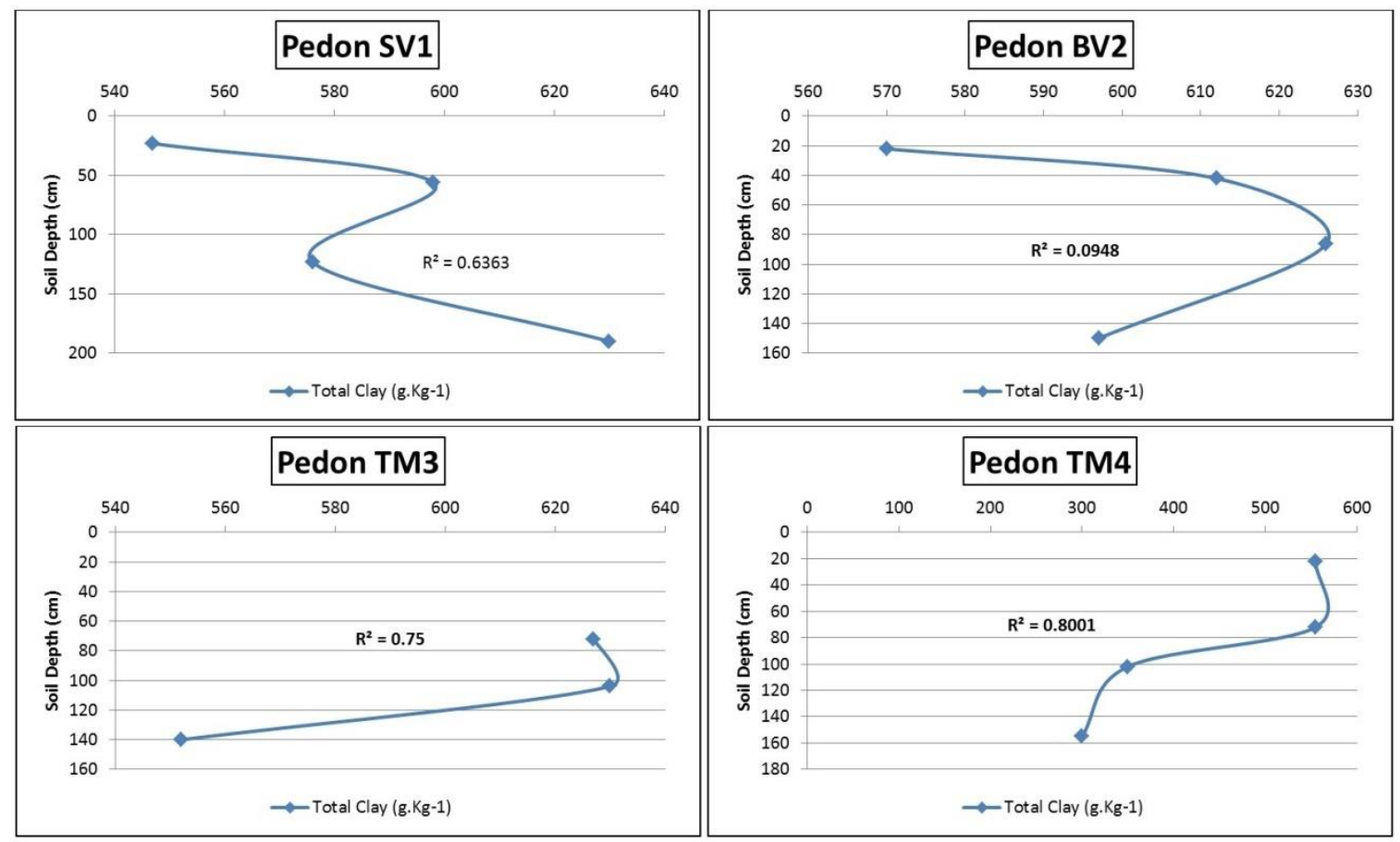

Fig. (5): Vertical distribution of clay particles in study pedons

\section{CONCLUSIONS}

The study soils were slightly alkaline and non-saline. The Vertisols contained considerable organic matter content but less than it in Mollisols, and organic matter oscillation from one horizon to another in Vertisols. The total carbonates content in Mollisols were more amount than Vertisols. CEC values in Vertisols were relatively higher than in Mollisols along the down direction of the pedons, and CEC values with depth indicated the semi steady-state and gradually decrease but in Vertisols was relatively steadier than Mollisols. The bulk density was fluctuated among soil horizons in Vertisols whereas, an increase in bulk density values with depth in Mollisols. The distribution pattern of clay indicated the fluctuation with depth in Vertisols and high clay content found in Mollisols. The following pedogenic processes were dominant in both soil orders but with different intensities, alkalization, desalinization, humification, littering, calcification, lessivage, leaching, bioturbation, whereas pedoturbation occurred just in Vertisols.

\section{REFERENCES}

Black, C. A. 1965. Method of soil analysis. Am. Soc. Of Agronomy. No.9 Part 1 and 2.

Eswaran, H., Reich. P. F. 2005. World Soil Map. USDA Natural Resources Conservation Service, Washington, DC, USA
FAO. 2015. IUSS Working Group WRB: World Reference Base for Soil Resources 2014, Update 2015. World Soil Resources Reports 106, Rome. ISBN 978-92-5108369-7.

Janzen, H. H., Fixen, P. E., Franzluebbers, A. J., Hattey, J., Izaurralde, R. C., Ketterings, Q. M., Lobb, D. A. and Schlesinger, W.H. 2011. "Global prospects rooted in soil science," Soil Sci Soc Am J., 75:1-8.

Klute, A, (Ed). 1986. Method of Soil Analysis. Part 1: Physical and Mineralogical Methods, 2nd Edition. Agron. Monogr. 9, Madison WI.

Loeppert, R. and Suarez. D. 1996. Method of soil analysis part 3. Chemical methods. Soil Sci. Soc. Am. And Am. Soc. Agron., 677, S. Segoe Ed., Madison Wisconsin 53711, USA, SSSA. Book Series No. 5.

Muhaimeed, A. S., al-Jeboory, S. R., Saliem, K. A., Burt, R. and Chiaretti, J. V. 2013. Genesis and Classification of Selected Soils in an Arid Region of Central Iraq. Soil Horizons, 54(6), pp.1-13.

Muhaimeed, A. S., A. J. Saloom, K. A. Saliem, K. A. Alani and W. M. Muklef. 2014 Classification and Distribution of Iraqi Soils. International Journal of Agriculture 
Innovations and Research Volume 2, Issue 6, ISSN (Online) 2319-1473.

Pal, D. K., Dasog, G. S. and Bhattacharyya, T. 2009a. Pedogenetic processes in cracking clay soils (Vertisols) in tropical environments of India: a critique. J Indian Soc Soil Sci 57:422-432

Pal, D. K., Bhattacharyya, T. and Wani, S. P. 2012b. Formation and management of cracking clay soils (Vertisols) to enhance crop productivity: Indian experience. In: Lal R, Stewart BA(eds) World soil resources, Francis and Taylor, pp 317343.

Polemio, M. J. and Rhoads. J. D. 1977. Determination cation exchange capacity a new procedure for calcareous and gypsiferous soils. Soil Soc. Am. Proc. 18:365-368.

Rowell, L. 1996. Soil science .Methods and application .Reading. Univ. UK.

Sa'eb, A.K., Taimeh, A.Y. 1998. Properties and characterization of vertisols developed on limestone in a semi-arid environment. Journal of Arid Environments. Elsevier.

Singh, L. P., Parkash, B. and Singhvi, A. K. 1998. Evolution of the lower Gangetic Plain landforms and soils in West Bengal, India. Catena 33:75-104.

Soil Survey Staff. 1999. Soil taxonomy: A basic system of soil classification for making and interpreting soil surveys. 2nd ed. Agric. Handb. No. 436. USDA-NRCS. U.S. Govt. Print. Office, Washington, DC.

Soil Taxonomy. 2012. The Twelve Soil Orders: at the Wayback Machine, Soil \& Land Resources Division, College of Agricultural and Life Sciences, University of Idaho.

Walkley, A. and Black. I. 1965. Determination of organic matter. In:C. A. Black. Method of soil analysis. Part 2. Agronomy No. 9. Am. Soc. Of Agron., Inc. Madison, Wisconsin, $\quad$ P. 1373-1376. 